\title{
Papers
}

\section{The loyalty of football fans - We'll support you evermore?}

Received (in revised form): 7th November, 2003

\begin{abstract}
Alan Tapp
is Senior Lecturer in Marketing at Bristol Business School. Alan has published over 35 articles in leading journals and international conferences as well as a best-selling textbook. Much of his research has been sponsored by organisations, for example IBM, Christian Dior and The Chartered Institute of Marketing. He is on the Editorial Board of the Journal of Database Marketing \& Customer Strategy Management. He has undertaken research, consultancy and training for organisations as diverse as the NSPCC, The Institute of Direct Marketing, National Centre for Educational Technology, Business Strategies Ltd, The Royal Mail, The CIM, IBM and Coventry City Football Club. He is the author of 'Principles of direct and database marketing', now in its second edition.
\end{abstract}

\begin{abstract}
The conventional wisdom among football fans is that every supporter is unstintingly loyal to their adopted team. Indeed this was accepted by Parker and Stuart in their award winning paper 'The West Ham Syndrome'. ${ }^{1}$ However, more recent work by Tapp and Clowes $^{2}$ describes a much more complex and interesting picture than was hitherto thought to be the case. In this paper the author further reports on this supporter data focusing specifically on loyalty. Previously unreported data that compared season ticket holders with lapsed season ticket holders is analysed. Supporters are identified as possessing a variety of loyalty behaviours and attitudes, some of which exhibit loyalty patterns quite similar to, say, supermarket goods sectors. However, the underlying explanatory factors are quite different to those present in mainstream sectors. These are discussed.
\end{abstract}

Dr Alan Tapp

Bristol Business School, University of the West of England,

Coldharbour Lane,

Bristol,

BS16 1QY, UK.

Tel: +44 (0)117 3443439 ; Fax: +44 (0)117344 2289; e-mail:

Alan.Tapp@uwe.ac.uk

\section{INTRODUCTION: THE IMPORTANCE OF SPORT}

In recent years sport in general and football in particular has attracted increasing attention from business commentators, consultants and academics. These stakeholders have, to a large degree, used the language of business in analysing sports franchises. Football clubs are described routinely, and wrongly, as 'big businesses' on television and radio. (The world's biggest club by turnover is Manchester United, which has an income of about $\mathcal{N} 170 \mathrm{~m}$ per year: not a figure to impress many in the City.)
Football clubs are described as brands, supporters are called customers and so on. One might assume from this that the business of football would follow the typical rules of other, more mainstream business sectors. However, it is argued throughout this paper that this is not the case; indeed Mullin et al. ${ }^{3}$ point out that sport exhibits unique characteristics the product is inconsistent and unpredictable, and the marketer has little or no control over the core product. The subject matter for this paper is loyalty: to what extent does loyalty follow the 'rules' familiar to marketers? 


\section{COMPARING THE LOYALTY OF DIFFERENT SECTORS}

Mainstream businesses are increasingly aware that high levels of loyalty from their customers is a desirable outcome. However, while desirable, it is difficult to achieve and contains underlaying complexities. To address these complexities the author decided to look at the business of loyalty within the football sector, where loyalty is a highly meaningful concept within its customer base. ${ }^{4,5}$ The literature contains studies of a similar type, although comparisons between football and mainstream sectors were the subject of Parker and Stuart's work. ${ }^{6}$ Parker and Stuart quite rightly pointed out the importance of researching football supporters, describing how important football is in many people's lists of life's priorities. However, they also asserted - with little evidence - that football fans are very unlikely to change their allegiance, with exclusive brand loyalty being the norm.

Unfortunately, in what must have been a rush of blood to the head, they stated that 'levels of loyalty are only marginally affected by team success'. This is completely inaccurate. Analysis of crowd sizes stretching back to the Second World War shows beyond dispute that crowd sizes are related to a team's position in the league, and that teams lose support when they drop down the league. The exceptions to this — such as Manchester City's heroic support during their recent stints in Division Two - are so high profile precisely because they are exceptions.

In fact, football supporters' loyalty is extremely interesting. For a start, loyalty is important to them in a way that it is not to customers in most consumer sectors (how many shoppers will sing 'loyal customers' as they make their weekly trip to Asda?). Moreover, this linkage of loyalty with self worth means that it can be researched

comprehensively: the researcher can have a meaningful conversation about loyalty. Hence, loyalty was an important element in work the author and colleagues carried out into football fans between 1996 and 2000..$^{7-9}$ This paper reports on previously unreported research findings that cast doubt on the notion that loyalty can be taken for granted.

The literature offers various models of loyalty that are useful in helping us make sense of the findings below. Reichheld established that although satisfaction and loyalty are inextricably linked, satisfied or even very satisfied customers could still defect. ${ }^{10}$ In a number of studies looking specifically at fast-moving consumer goods (FMCGs), Ehrenberg found that consumers will tend towards auto-repurchase and that attitudes have only a weak input into subsequent behaviour. ${ }^{11}$ Research has also examined sports supporter behaviour. Bristow and Sebastian investigated the 'under-dogging' of Chicago Cubs fans in the USA. ${ }^{12}$ The Cubs are perennial under-achievers, but the worse they do, the more the fans will support them. Fans' self worth is defined by their loyalty 'against the odds'. Buchanan noted the importance of calculative, affective and moral (self image) constructs in a model of commitment in leisure services. ${ }^{13}$ Hence there is evidence that loyalty to one's sports club straddles logical, emotional and ethical divides of the human psyche.

The next section explains the author's research approach, before moving on to the findings.

\section{PRIMARY RESEARCH}

The author and colleagues developed a relationship with a Premier League football club between 1996 and 2000 . 
Over the four-year collaboration, data was collected as follows:

- 25 qualitative in-depth interviews were conducted with supporters between February and April 1998;

- numerous semi-structured and unstructured conversations were held with customer-facing executives at the club from 1996-2000;

- three quantitative surveys: to 667 supporters in November 1998 carried out at the ground on a match day; to 397 attenders of a club open day in June 1999; and a final survey conducted in November 2000 with the objective of comparing current and lapsed season ticket holders. A total of 411 usable responses were obtained;

- analyses of the club's supporter database;

- occasional, ad hoc, match day observations.

Some of the data captured has already been reported. ${ }^{14}$ Here the author reports on new insights on loyalty previously unreported.

A number of factors contributed towards the selection of a qualitative approach to supplement the survey data. It was felt that a high degree of trust and understanding needed to be present between researcher and respondent in order to discuss sensitive topics such as the reasons behind lack of supporter loyalty. Churchill argues the case for the shift from positivism (scientific methodologies) to constructivism (social science methodologies) in cases like this. ${ }^{15}$ In this project, although quantitative research was used, it was deployed inductively rather than deductively. Preliminary interviews revealed a distinct divergence of perspectives on personal motives and beliefs, which would be very difficult to assess using only objective methodologies.
It was found that there was a need to minimise both ego defensiveness (protecting one's self image) and 'socially desirable responding' (protecting one's social image) from supporters who defined themselves as loyal, 'true' fans. ${ }^{16}$

Projective techniques were deployed as appropriate in the qualitative phase. The use of compared samples in the final quantitative phase removed the need for direct questioning about loyalty. Instead, a loyalty instrument developed by Mahoney et al. was employed to highlight any differences between loyal and less loyal supporters. In the November 2000 survey, the sample frame was divided into those who had renewed (current season ticket holders) and those who had not (lapsed). Based on the exploratory work, questions focused on the following elements: personal profile data, affective and conative attitudes to loyalty; affective attitudes to football as entertainment; the decision-making process of attending and how this may be influenced; and conative attitudes towards non-match day activities.

The data were subsequently analysed using Pinpoint and SPSS software. Chi square analysis was used to test for significance between groups. All of the data presented below were found to be significant for this test at $p<0.05$.

\section{RESULTS}

To begin with, the different types of loyalty exhibited by different types of fans are examined. This sets the scene for a more detailed analysis later in the paper, which attempts to identify contributory factors to the different levels of loyalty described.

\section{The loyalty of football fans}

Analyses of football crowd size data going back to the inter-war period found 
Table 1: Extent to which supporters describe themselves as loyal

\begin{tabular}{|c|c|c|c|c|c|c|c|}
\hline \multicolumn{8}{|c|}{ Agreement with statement: 'I would see myself as a loyal supporter' } \\
\hline $\begin{array}{l}\text { No. of games } \\
\text { attended }\end{array}$ & $\begin{array}{l}\text { Not } \\
\text { answered }\end{array}$ & $\begin{array}{l}\text { Less } \\
\text { than } 5\end{array}$ & $\begin{array}{l}\text { Between } 5 \\
\text { and } 9\end{array}$ & $10-18$ & $\begin{array}{l}\text { All home } \\
\text { games }\end{array}$ & $\begin{array}{l}\text { All home } \\
\text { some or } \\
\text { away }\end{array}$ & Total \\
\hline Not answered & $\begin{array}{l}42 \\
(95 \%)\end{array}$ & 0 & 0 & 0 & $\begin{array}{c}1 \\
(1 \%)\end{array}$ & $\begin{array}{c}1 \\
(1 \%)\end{array}$ & $\begin{array}{c}44 \\
(7 \%)\end{array}$ \\
\hline Agree strongly & $\begin{array}{c}2 \\
(5 \%)\end{array}$ & $\begin{array}{l}27 \\
(33 \%)\end{array}$ & $\begin{array}{l}41 \\
(53 \%)\end{array}$ & $\begin{array}{l}59 \\
(71 \%)\end{array}$ & $\begin{array}{l}165 \\
(88 \%)\end{array}$ & $\begin{array}{l}181 \\
(93 \%)\end{array}$ & $\begin{array}{l}475 \\
(71 \%)\end{array}$ \\
\hline Agree slightly & 0 & $\begin{array}{l}25 \\
(31 \%)\end{array}$ & $\begin{array}{l}29 \\
(38 \%)\end{array}$ & $\begin{array}{l}23 \\
(28 \%)\end{array}$ & $\begin{array}{l}21 \\
(11 \%)\end{array}$ & $\begin{array}{c}11 \\
(6 \%)\end{array}$ & $\begin{array}{l}109 \\
(16 \%)\end{array}$ \\
\hline Disagree slight & 0 & $\begin{array}{l}19 \\
(23 \%)\end{array}$ & $\begin{array}{l}6 \\
(8 \%)\end{array}$ & $\begin{array}{c}1 \\
(1 \%)\end{array}$ & $\begin{array}{c}1 \\
(1 \%)\end{array}$ & $\begin{array}{c}1 \\
(1 \%)\end{array}$ & $\begin{array}{c}28 \\
(4 \%)\end{array}$ \\
\hline Disagree strongly & 0 & $\begin{array}{l}10 \\
(12 \%)\end{array}$ & $\begin{array}{c}1 \\
(1 \%)\end{array}$ & 0 & 0 & 0 & $\begin{array}{c}11 \\
(2 \%)\end{array}$ \\
\hline Total & 44 & 81 & 77 & 83 & 188 & 194 & 667 \\
\hline
\end{tabular}

Note: Percentages may not add up to $100 \%$ due to rounding

that, in general, most clubs see support rising and falling more or less in direct correlation to their success on the field. ${ }^{18}$ It will be true that data based on crowd totals is likely to be a misleading indicator of individual loyalties, but nevertheless it would not be unfair to summarise that a significant sector of supporters are not sticking with their teams through thick and thin. This was the authors' initial stance in designing this research. Analysis quite quickly revealed a rather complex behavioural loyalty picture.

\section{Attitudinal and behavioural loyalty linked}

The authors asked supporters about the extent to which they agreed with the phrase: 'I would describe myself as a loyal supporter' (November 1998 survey). Not surprisingly, 87 per cent of all fans either strongly agreed or agreed slightly with this statement. Interestingly, the fan base of the club under study here has dropped from 24,000 to about 16,000 at the time of writing, demonstrating the differences between attitude and behaviour on this subject. Table 1 summarises the relationship between attitudinal loyalty and behaviour. ${ }^{19}$
While most fans saw themselves as loyal, their behaviour ran across the loyalty spectrum. In a typical average crowd of about 21,000, about 8,000 fans were season ticket holders, with the author's survey data about attendance and subsequent crowd sizes suggesting that another 8,000 places were made up from about 15,000 or so regular attenders. The remaining 5,000 fans were made up of a 'revolving door' of perhaps 20,000 'casual fans'.

\section{Fanatics}

At the top end of the scale, the sizeable presence of highly committed fans (fanatics) was no surprise. Their loyalty to the club was active and consciously expressed and in many cases a sizeable part of their self image. Many were avid collectors of club memorabilia ${ }^{20}-\mathrm{a}$ strong reminder of their sense of self, and very important in their lives:

'So, hypothetically, if there was a fire in your house, what would you save first?'

'Oh my programmes and tapes. No question.

\{Points to drawer\}.

And my wife and kids of course.'

Male, fanatic, 40s 
Table 2: Segmentation of light attenders (casuals)

Carefree casuals $(57 \%$ of casuals)

- Defined as those casuals who only slightly agree, or disagree, with the notion that they are loyal supporters.

- $88 \%$ of carefree casuals prefer to see an entertaining game, even if the club loses.

- $50 \%$ of carefree casuals attend matches not involving the club, compared to $29 \%$ of all fans.

- $88 \%$ describe watching football as just one of a number of choices for them on a Saturday.

- $63 \%$ don't know when the club's next home game is.

- Summary: 'carefree casuals' may be football lovers, but see the club as an entertainment option, being club supporters is not part of their self image.

Committed casuals $(43 \%$ of casuals)

- Defined as those casuals who strongly agree that they are loyal to the club.

- Only $26 \%$ attend matches not involving the club.

- $38 \%$ think that the club winning the match is more important than an entertaining game (close to the percentage of fanatics who think the same).

- $78 \%$ of committed casuals know when the club's next game is. However, $75 \%$ still see watching the club as one of a range of things they will consider.

- Summary: 'committed casuals' are genuine fans of the club, but for them some non-football activities are of equal or greater priority. Income was not an issue. They therefore value variety and choice, and perhaps have their football support in perspective with the rest of their lives.

\section{Repertoire fans}

In the November 1998 survey the authors asked fans whether they regularly watched games NOT involving their team, and were very surprised by the answer: an incredible 27 per cent said they did. This is completely at odds with the tribalism presumed to be at the heart of football support. Derby fans, for instance, would be surprised to hear that some of their number went to watch Nottingham Forest sometimes. But this is what appears to be happening. This is not 'brand switching' (moving support from one club to another), however; brand switching is much rarer. ${ }^{21}$ No, this behaviour is more akin to 'repertoire buying' of the sort that is familiar to FMCG marketers. The majority of these supporters were also heavy watchers of their supported team: they primarily watched these 'other' games when their own team were playing away. Other matches that they attended involved Premier League, Football League and local non-league teams. What emerged from the qualitative phase was a distinct difference in attitude to the sport itself: repertoire fans took a lot of pleasure from a multiplicity of aspects of the game itself, while single club fanatics were less interested in football, more devoted to the club as an entity.

\section{Season ticket churn}

The precise extent of the Pareto principle (80-20 rule) cannot be exactly calculated from the data to hand, but it is likely to be significant. While the percentage of seats occupied by season ticket holders varies, they are certainly responsible for most of the merchandise and non-football item sales for most clubs. They are the most valuable customers and are considered by executives to be unstintingly loyal people who will turn up for each game year in, year out. Simple analysis of the database at the club analysed here revealed a different picture, however. Of 8,000 season ticket holders, each season about 1,000 were subject to churn - not renewing their tickets and being replaced by one thousand others. So, even at the fanatic end, the loyalty bucket had significant leaks. 


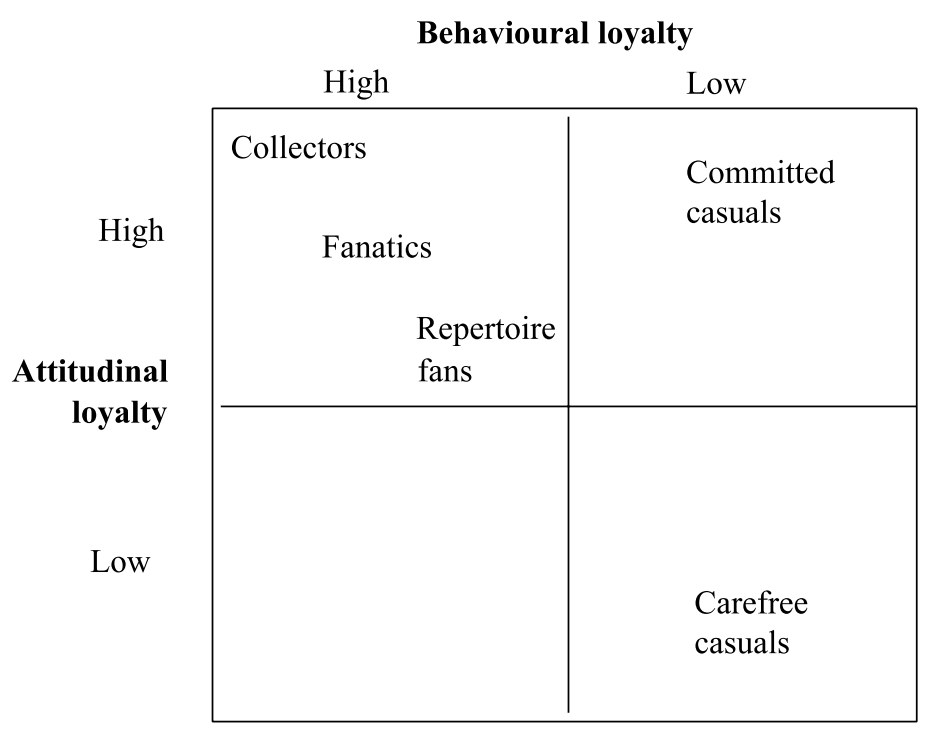

Figure 1: Dick and Basu framework applied to football supporters

\section{Casual fans: Football a lifestyle option?}

At the other end of the spectrum, the club was aware of a sizeable number of supporters whose behavioural loyalty was much lower: they attended typically less than five games per season. These 'casual fans' formed part of the qualitative research and, for some of them, attitudes were very different to those of 'fanatics'.

'I can take it or leave it to be honest. It's entertainment on a Saturday.

We wake up in the morning and think shall we go to the footy today?'

Casual fan, male, mid 30s.

These 'carefree casuals' would often be happier to see an exciting 3-2 loss for their team than a boring $1-0$ win. Other low attenders were quite the opposite, however. These supporters were highly committed attitudinally and saw themselves as very loyal.

Table 2 summarises the differences between 'carefree' (low attitudinal and behavioural loyalty) casuals and 'committed' (high attitudinal and low behavioural loyalty) casuals.
The Dick and Basu framework can be used to summarise the different supporter categories. $^{22}$ (See Figure 1.)

In the next section, the paper offers some expansion of the data surrounding loyalty issues and introduces a number of theoretical underpinnings.

\section{ANTECEDENTS AND CONSEQUENCES OF LOYALTY}

Of all its possible constructs, loyalty has most famously been linked with satisfaction. It is now well known that satisfaction is no guarantee of loyalty - customers who say they are satisfied may well defect. More interestingly here, customer dissatisfaction is, almost without exception, linked to switching in markets where switching is possible. ${ }^{23,24}$ To unravel the complexities of these links in the context of sport, the authors started by looking at attitudinal loyalty and cross tabulating it with satisfaction with the team performance. It was found that levels of dissatisfaction in one season were found to be worryingly high; yet in 
Table 3: How satisfied are you with the team's performance this season versus agreement with statement 'I would describe myself as a loyal supporter'

\begin{tabular}{|c|c|c|c|c|c|c|}
\hline & $\begin{array}{l}\text { Not } \\
\text { answered }\end{array}$ & $\begin{array}{l}\text { Agree } \\
\text { strongly }\end{array}$ & $\begin{array}{l}\text { Agree } \\
\text { slightly }\end{array}$ & $\begin{array}{l}\text { Disagree } \\
\text { slight }\end{array}$ & $\begin{array}{l}\text { Disagree } \\
\text { strongly }\end{array}$ & Total \\
\hline Not answered & $\begin{array}{l}42 \\
(95 \%)\end{array}$ & 0 & 0 & 0 & 0 & $\begin{array}{l}42 \\
(6 \%)\end{array}$ \\
\hline Very satisfied & 0 & $\begin{array}{l}9 \\
(2 \%)\end{array}$ & 0 & 0 & $\begin{array}{c}2 \\
(18 \%)\end{array}$ & $\begin{array}{l}11 \\
(2 \%)\end{array}$ \\
\hline Satisfied & 0 & $\begin{array}{l}182 \\
(38 \%)\end{array}$ & $\begin{array}{l}38 \\
(35 \%)\end{array}$ & $\begin{array}{l}10 \\
(36 \%)\end{array}$ & $\begin{array}{c}3 \\
(27 \%)\end{array}$ & $\begin{array}{l}233 \\
(35 \%)\end{array}$ \\
\hline Dissatisfied & $\begin{array}{l}2 \\
(5 \%)\end{array}$ & $\begin{array}{l}272 \\
(57 \%)\end{array}$ & $\begin{array}{l}66 \\
(61 \%)\end{array}$ & $\begin{array}{l}15 \\
(54 \%)\end{array}$ & $\begin{array}{c}4 \\
(36 \%)\end{array}$ & $\begin{array}{l}359 \\
(54 \%)\end{array}$ \\
\hline Very dissatisfied & 0 & $\begin{array}{l}12 \\
(3 \%)\end{array}$ & $\begin{array}{l}5 \\
(5 \%)\end{array}$ & $\begin{array}{c}3 \\
(11 \%)\end{array}$ & $\begin{array}{c}2 \\
(18 \%)\end{array}$ & 22 \\
\hline Total & 44 & 475 & 109 & 28 & 11 & 667 \\
\hline Chi-Square & & & & & 670.538 & \\
\hline
\end{tabular}

Note: Percentages may not add up to $100 \%$ due to rounding

Table 4: Satisfaction with the club performance versus number of games attended. Agreement with statement: How satisfied are you with the club performance this season?

\begin{tabular}{|c|c|c|c|c|c|c|}
\hline $\begin{array}{l}\text { Number of games } \\
\text { attended }\end{array}$ & $\begin{array}{l}\text { Less than } \\
5\end{array}$ & $\begin{array}{l}\text { Between } 5 \\
\text { and } 9\end{array}$ & Ten to 18 & $\begin{array}{l}\text { All home } \\
\text { games }\end{array}$ & $\begin{array}{l}\text { All home and } \\
\text { some or all } \\
\text { away games }\end{array}$ & Total \\
\hline Very satisfied & $\begin{array}{l}4 \\
(5 \%)\end{array}$ & 0 & 0 & $\begin{array}{l}4 \\
(2 \%)\end{array}$ & $\begin{array}{l}3 \\
(2 \%)\end{array}$ & $\begin{array}{l}11 \\
(2 \%)\end{array}$ \\
\hline Satisfied & $\begin{array}{l}29 \\
(36 \%)\end{array}$ & $\begin{array}{l}29 \\
(38 \%)\end{array}$ & $\begin{array}{l}25 \\
(30 \%)\end{array}$ & $\begin{array}{l}75 \\
(40 \%)\end{array}$ & $\begin{array}{l}74 \\
(38 \%)\end{array}$ & $\begin{array}{l}232 \\
(37 \%)\end{array}$ \\
\hline Dissatisfied & $\begin{array}{l}39 \\
(48 \%)\end{array}$ & $\begin{array}{l}46 \\
(60 \%)\end{array}$ & $\begin{array}{l}56 \\
(67 \%)\end{array}$ & $\begin{array}{l}107 \\
(57 \%)\end{array}$ & $\begin{array}{l}110 \\
(57 \%)\end{array}$ & $\begin{array}{l}358 \\
(57 \%)\end{array}$ \\
\hline Very dissatisfied & $\begin{array}{c}9 \\
(11 \%)\end{array}$ & $\begin{array}{l}2 \\
(3 \%)\end{array}$ & $\begin{array}{l}2 \\
(2 \%)\end{array}$ & $\begin{array}{l}2 \\
(1 \%)\end{array}$ & $\begin{array}{l}7 \\
(4 \%)\end{array}$ & $\begin{array}{l}22 \\
(4 \%)\end{array}$ \\
\hline Total & 81 & 77 & 83 & 188 & 194 & 623 \\
\hline
\end{tabular}

Note: Percentages may not add up to $100 \%$ due to rounding

the same survey almost all supporters described themselves as loyal (Table 3).

We then looked at the link between satisfaction and behavioural loyalty: again, there was remarkably little effect (Table 4).

On the face of it these are surprising results: satisfaction appears to have little or no link at all to loyalty. It was decided to take a closer look at one particular group: lapsed season ticket holders - by definition having recent low behavioural loyalty.

A comparative analysis of current season ticket holders with recently lapsed season ticket holders was carried out in November 2000. Four hundred and eleven respondents were questioned on a whole battery of factors using a loyalty survey instrument developed by Mahoney et al. ${ }^{25}$ and chi-square analysis was used to discriminate between the two samples. The key findings are illustrated in Tables $5 \mathrm{a}-5 \mathrm{~d}$.

Tables $5 \mathrm{a}-5 \mathrm{~d}$ compare lapsed supporters with current season ticket holders. The results show that supporters that did not renew their season tickets were more likely to agree that they led complicated lives; and were more likely to have one child under five years of age. In addition, although incomes were similar, ex-season ticket holders were more likely to agree that they found it 
Table 5: Comparing season ticket holders with lapsed season ticket holders on various statements a) Respondents' agreement that they are loyal

\begin{tabular}{llllll}
\hline & $\begin{array}{l}\text { Agree } \\
\text { strongly }\end{array}$ & $\begin{array}{l}\text { Agree } \\
\text { slightly }\end{array}$ & $\begin{array}{l}\text { Disagree } \\
\text { slightly }\end{array}$ & $\begin{array}{l}\text { Disagree } \\
\text { strongly }\end{array}$ & Total \\
\hline I do not have a season & 86 & 22 & 4 & 1 & 116 \\
ticket this season & $(24 \%)$ & $(55 \%)$ & $(100 \%)$ & $(100 \%)$ & $(27 \%)$ \\
I have a season ticket & 274 & 18 & 0 & 0 & 292 \\
for 1999/2000 & $(76 \%)$ & $(45 \%)$ & & & $(71 \%)$ \\
Total & 360 & 40 & 4 & 1 & 405 \\
\hline
\end{tabular}

b) Respondents with children aged under 5

\begin{tabular}{lllll}
\hline & $\mathbf{0}$ & $\mathbf{1}$ & $\mathbf{2}$ & Total \\
\hline I do not have a season & 72 & 18 & 2 & 92 \\
ticket this season & $(26 \%)$ & $(44 \%)$ & $(25 \%)$ & $(27 \%)$ \\
I have a season ticket & 210 & 23 & 6 & 239 \\
for 1999/2000 & $(74 \%)$ & $(56 \%)$ & $(75 \%)$ & $(71 \%)$ \\
Total & 282 & 41 & 8 & 331 \\
\hline
\end{tabular}

c) Agreement with statement: 'I lead a complicated life'

\begin{tabular}{llllll}
\hline & $\begin{array}{l}\text { Agree } \\
\text { strongly }\end{array}$ & $\begin{array}{l}\text { Agree } \\
\text { slightly }\end{array}$ & $\begin{array}{l}\text { Disagree } \\
\text { slightly }\end{array}$ & $\begin{array}{l}\text { Disagree } \\
\text { strongly }\end{array}$ & Total \\
\hline I do not have a season & 25 & 41 & 21 & 24 & 111 \\
ticket this season & $(66 \%)$ & $(44 \%)$ & $(20 \%)$ & $(15 \%)$ & $(27 \%)$ \\
I have a season ticket & 13 & 52 & 83 & 133 & 281 \\
for 1999/2000 & $(34 \%)$ & $(56 \%)$ & $(80 \%)$ & $(84 \%)$ & $(71 \%)$ \\
Total & 38 & 93 & 104 & 157 & 392 \\
\hline
\end{tabular}

d) Respondents' age bracket

\begin{tabular}{lccccccc}
\hline & Under $\mathbf{1 8}$ & $\mathbf{1 9 - 3 4}$ & $\mathbf{3 5 - 4 4}$ & $\mathbf{4 5 - 5 4}$ & $\mathbf{5 5 - 6 4}$ & $\mathbf{6 5 +}$ & Total \\
\hline I do not have a season & 18 & 47 & 24 & 13 & 7 & 3 & 112 \\
ticket this season & $(42 \%)$ & $(39 \%)$ & $(28 \%)$ & $(16 \%)$ & $(17 \%)$ & $(10 \%)$ & $(28 \%)$ \\
I have a season ticket & 25 & 72 & 62 & 66 & 35 & 27 & 287 \\
for 1999/2000 & $(58 \%)$ & $(61 \%)$ & $(72 \%)$ & $(84 \%)$ & $(83 \%)$ & $(90 \%)$ & $(72 \%)$ \\
Total & 43 & 119 & 86 & 79 & 42 & 30 & 399 \\
\hline
\end{tabular}

hard 'to justify the spend this year'. Interestingly, factors which did not appear to have any bearing included satisfaction with the team and preferences for winning versus entertaining matches.

What is clear is that loyalty thrives when the supporter is older, more settled, perhaps with fewer complicated commitments and has a long history of prior support. This is a familiar story in many mainstream sectors. For instance, the credit card firm MBNA studied its customer base and found that older, more settled people in teaching, accountancy and nursing were more likely to be loyal. ${ }^{26}$ Theoretically, one could envisage the auto-repurchase mechanism first developed by Ehrenberg $^{27}$ who found that attitudes have only a weak input into subsequent behaviour in many FMCG markets. It may be that older supporters, leading settled lives, have simply settled into some form of auto-repurchase.

Interestingly, there was only a small correlation between income and loyalty in the sense of season ticket renewal. There was a hint that supporters who 
renewed were slightly wealthier on average, but the qualitative back up suggests that income per se was not a key driver. It is, however, an enabler indeed a government task force was set up to address the issue of social exclusion of fans for Premier League games in particular. An interesting perspective on income is revealed by going back in time: watching football was traditionally a working class pursuit, suggesting that the roots of loyalty here do not lie with the wealthy middle class. Indeed it may be that over a long time frame (not part of this study, of course) we may see the middle class move away from football as another 'trend' emerges. At this stage this is no more than speculation however.

Social class has an interesting overlay effect with football support. Our observations about ticket sales suggest an unsurprising link of face-to-face purchase (with cash) among working class fans. Meanwhile credit card telephone bookers tended to be more up-market.

Many of the most fanatical supporters are much younger than these settled older fans, so other explanations were sought through qualitative techniques. In depth interviews carried out at different times between 1996 and 2000 found strong links between support with self-concept. Much work in this area has been done by Buchanan, ${ }^{28}$ who suggested that:

'It is at this highest level that the norms of an activity are considered right in terms of self-identity, and obedience to norms is regarded as a moral necessity.'

Buchanan found that strong attitudes could nonetheless accompany low frequency or behavioural participation but reasoned that this could be due to situational influences not measured, such as time and money. This is analogous to the 'committed casuals' segment identified by the author. Attitudes, therefore, may not be reflected in behaviour:

'High levels of commitment, therefore can exist without the appearance of behavioural consistency, provided behaviour is consistent relative to the role identities and values of the individual'.

In addition to self image, social self image - ways in which we want others to view us - are also extremely important. They will reach a peak when supporters feed loyalty itself into their self image: 'we are loyal supporters'. When this happens, loyalty becomes independent of the team itself, and focuses inwards to oneself. This can be understood further by applying the theory of underdogging. Lang and Lang found a tendency to 'back the underdog' in certain circumstances. ${ }^{29}$ This is often considered to be a very British trait. It has also been found in US sport: Bristow and Sebastian observed that followers of unsuccessful clubs tended to downgrade their expectations of 'product performance'. ${ }^{30}$ More poignantly, the very act of being so loyal against the odds was what attracted them: maybe it was 'bloody mindedness', but in a sense the worse the team did, the more bonded to each other and to the team they became. Bristow and Sebastian noted that Chicago Cubs' fans felt that by supporting a team of 'no-hopers', they belonged to something special that outsiders didn't really understand. ${ }^{31}$ The team's subsequent success can actually lead to resentment as more casual fans then become attracted. This is not to suggest that success is not popular. Success can lead to the well known sports supporter phenomenon of BIRGing - Basking In Reflected Glory $^{32}$ in which supporters of successful teams use that association to symbolise 
themselves. In the study reported here, however, the team's mediocre record precluded any testing of the BIRGing effect.

Bristow and Sebastian found that, compared to less loyal fans, greater numbers of die-hard Chicago Cubs fans would report having watched and/or listened to the Chicago Cubs baseball games during their childhood. ${ }^{33}$ They pointed out that such a prediction is consistent with the severity of initiation effects, ${ }^{34,35}$ which suggests that the more a person voluntarily suffers to join a group (or achieve some end), the more positively the individual will evaluate the group or end. This was replicated in the author's present research. In the qualitative research the author found evidence of a 'childhood' effect among 'fanatic' respondents, who were very proud of their long relationship with the club.

'Oh yes, my dad took me back in the '60s. I went a lot as a kid. I'm quite proud of that now.'

Committed fan, male, 50s

The author found community effects to add to Bristow and Sebastian's longevity effect. $^{36}$

'It's not much to look at, but it's my city.

The club's our (local people) club -

something to feel a part of.'

Fanatic, female, 20s

In contrast more casual fans tended not to have club links going back very far. They had often moved to the area as adults, and their ties were weaker.

\section{A new model of supporter loyalty}

Figure 2 attempts to bring together all the above behavioural, attitudinal and demographic factors into one model. For each identified segment, a different version of this model will play out; in each case the antecedents of attitude and behaviour may be different.

An attempt has been made in Figure 3 to indicate how the model may differ for low, medium and high levels of behavioural loyalty. For all the undoubted importance of psychological factors, in particular self image, the consequence of this model could be that, in fact, the most important factors in identifying future defectors from the pool of supporters could be demographic or transaction-related.

\section{CONCLUSION}

The conclusion of this work is that sports supporter loyalties are more complex than is suggested by the simple conventional wisdom that all fans will 'support you evermore'. In fact, a series of behavioural, demographic and attitudinal factors are particularly important. The most important issue for sports marketers seeking to use direct marketing to target their fans is that loyalty cannot be relied upon. They need to look under the surface of supporter loyalty to uncover a belief system that is closer to concepts like self image, community belonging, backing the underdog and BARG, than it is to product satisfaction, service delivery and the like. In these senses, sport as a product is fundamentally different to those in more mainstream sectors.

The complexity of different supporter segments and the very different needs of each support a database-driven approach to football club marketing strategies. The recommendation of this work is that database analysis is carried out on the supporter base on a club-by-club basis to establish the size and validity of different segments.

In this paper the club figures for 


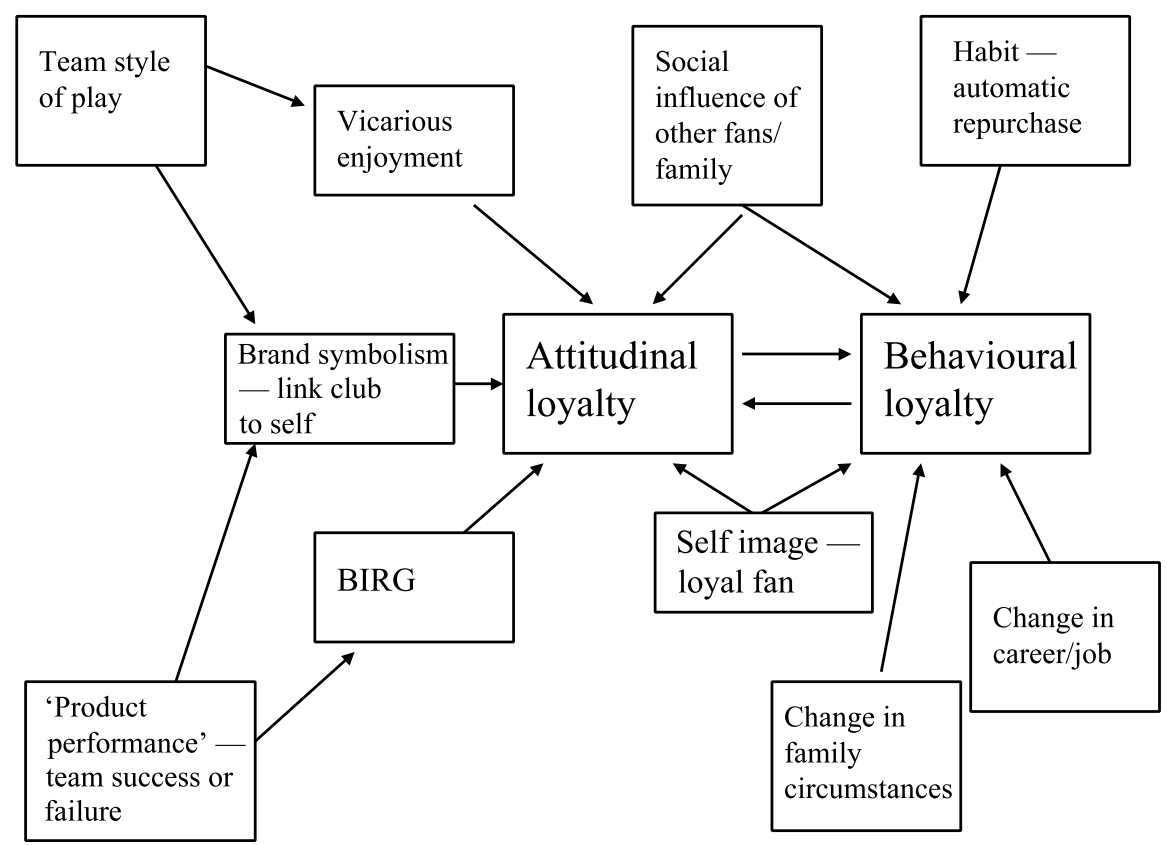

Figure 2: Factors impacting on attitudinal and behavioural loyalty

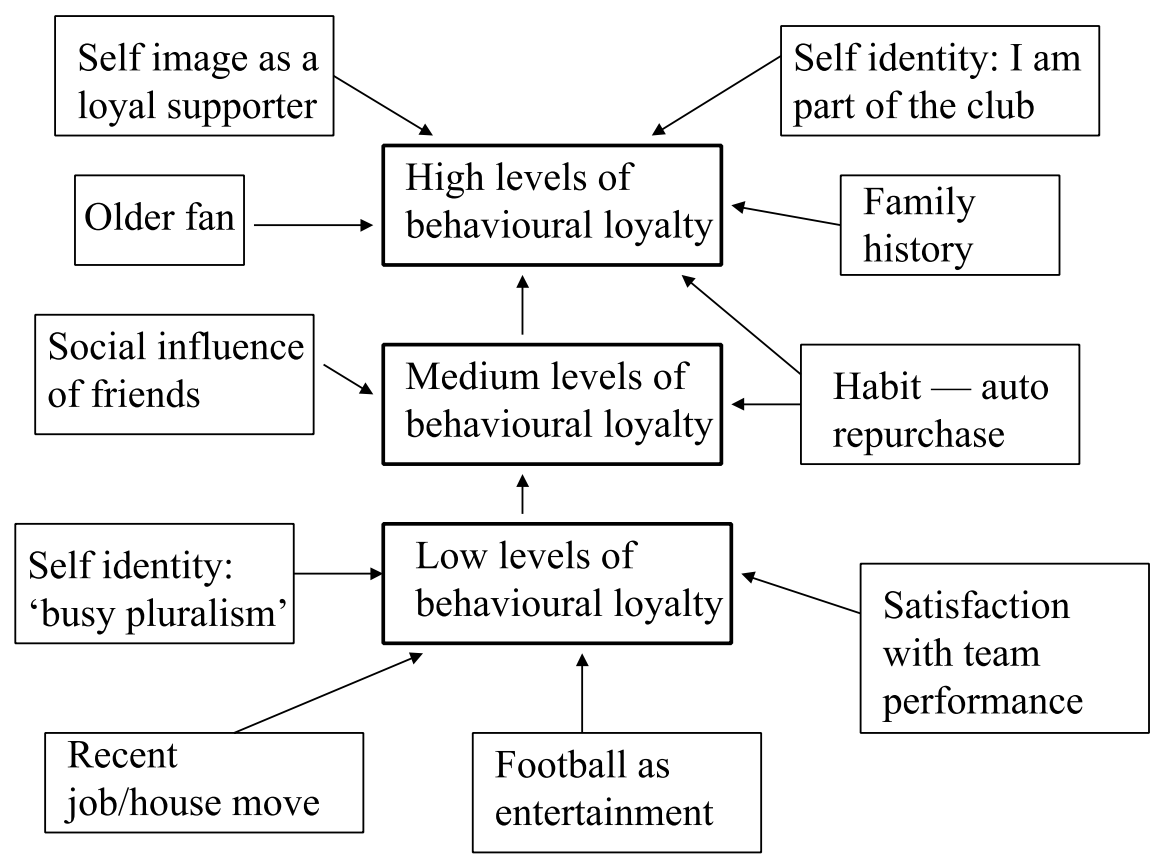

Figure 3: Differing levels of loyalty - key factor 
different segments were identified these will, of course, vary by club but do give a feel for what will be sizeable lifetime values compared to many other sectors. Individual data on key variables concerned with age, occupation, self concept, attitude to the club/to football and behaviour should be gathered to enable each fan to be assigned to the correct 'loyalty segment'. Only then can the direct marketers consider themselves ready to take on the challenge of accurately understanding what makes their sports customers tick.

\section{Limitations of this work}

This is an in-depth study of the supporters of one club. While this affords insights that broader studies might miss, it does mean the external validity of the findings is at present rather low. It should be pointed out that each football club is unique in the sense that the loyalty drivers will be different in each case. Local cultures, geography, social make up and the size and success of the club will all impact on loyalty.

In this study the club involved was town based, within a fairly built up, broad area, and with other clubs (including some seen as rivals) relatively close by. The club had a turnover typically within the $\mathcal{N}^{20-30}$ million range. Hence the fabric of loyalty for a club with a global following (Manchester United?) will be different, as will that for a very small local club such as York City. This author would speculate that Manchester United would have a large number of fanatical fans, as well as a large number of casual fans. York City's fan base is more likely to be made up of fanatics, possibly with significant 'underdogger' attitudes. The presence of local rivals tends to increase the fanaticism at that end of the spectrum (football is seen as tribal and competitive), while having little effect either way on casuals' attitudes to football (football is seen as entertainment).

There are a number of wider non-club related 'halo' effects that were not studied here. Events such as World Cup championships, especially if they involve good England performances, would be likely to have a halo effect in increased interest at club level for English clubs. There is a substantial literature on hooliganism, at its height in the 1970s and 1980s, and with a worrying growth in the 2002-03 season across Europe, which examines the socio-cultural backgrounds of hooligans. Their impact on loyalty was touched upon here: supporters tended to just keep out of their way, though female fans, not surprisingly, were potentially less likely to attend if they felt threatened. However, once more, further in-depth study is required.

\section{References}

1 Parker, K. and Stuart, T. (1997) 'The West Ham Syndrome', Journal of the Market Research Society, Vol. 39, No. 3, July, pp. 509-517.

2 Tapp, A. and Clowes, J. (2002) 'From "Carefree Casuals" to "Professional Wanderers":

Segmentation possibilities for football supporters', European Journal of Marketing, Vol. 36, No. 11.

3 Mullin, B. J., Hardy, S. and Sutton, W. (2000) 'Sport marketing', Human Kinetics, Champaign, IL.

4 Dick, A. S. and Basu, K. (1994) 'Customer loyalty: Toward an integrated conceptual framework', Journal of Academy of Marketing Science, Vol. 22, No. 2, pp. 99-113.

5 Sheth, J. N. and Parvatiyar, A. (1995) 'Relationship marketing in consumer markets: antecedents and consequences', Journal of the Academy of Marketing Science, Fall, Vol. 23, No. 4, pp. 255-271.

6 Parker and Stuart (1997) op. cit.

7 Clowes, J. and Tapp, A. (1998) 'From the 4P's to the 3R's. Using relationship marketing to retain football clubs' supporters and improve income', Managing Leisure, Vol. 3, No. 1, pp. 18-26.

8 Tapp, A., Beech, J. and Chadwick, S. (1999) 'The culture of collecting: An opportunity for football clubs', Journal of Database Marketing, Vol. 6, No. 3, pp. 253-266. 
9 Tapp and Clowes (2002) op. cit.

10 Reichheld, F. F. (1996) 'The loyalty effect', Harvard Business School Press, Boston.

11 Ehrenberg, A. S. C. (1972) 'Repeat buying, theory and applications', North Holland, London.

12 Bristow, D. and Sebastian, R. (2001) 'Holy cow! Wait 'til next year! A closer look at the brand loyalty of Chicago Cubs baseball fans', Journal of Consumer Marketing, Vol. 18, No. 3.

13 Buchanan, T. (1985) 'Commitment and leisure behaviour: A theoretical perspective', Leisure Sciences, Vol. 7, No. 4, pp. 401-420.

14 Tapp and Clowes (2002) op. cit.

15 Churchill, G. A. (1995) 'Marketing research methodological foundations', 6th edn, Dryden, USA.

16 Malhotra, N. (1996) 'Marketing research, An applied orientation', 2nd edn, Prentice Hall, Harlow, Pearson.

17 Mahoney, D. F., Madrigal, R. and Howard, D. (1999) 'The effect of individual levels of self monitoring on loyalty to professional football teams', International Journal of Sports Marketing E Sponsorship, Vol. 1, No. 2, pp. 146-168.

18 Russell, D. (1997) 'Football and the English', Carnegie, UK.

19 Based on the framework of loyalty devised by Dick and Basu (1994) op. cit.

20 Tapp et al. (1999) op. cit.

21 Tapp and Clowes (2002) op. cit.
22 Dick and Basu (1994) op. cit.

23 Reichheld (1996) op. cit.

24 Athanassopoulos, A., Gounaris, S. and Stathakopoulos, V. (2001) 'Behavioural responses to customer satisfaction: An empirical study', European Journal of Marketing, Vol. 35, No. 5/6, pp. 687-708.

25 Mahoney et al. (1999) op. cit.

26 Reichheld (1996) op. cit.

27 Ehrenberg (1972) op. cit.

28 Buchanan (1985) op. cit.

29 Lang, K. and Lang, G. (1984) 'The impact of polls on public opinion', The Annals of the American Academy of Political and Social Sciences, Vol. 472, pp. 129-42.

30 Bristow and Sebastian (2001) op. cit.

31 Ibid.

32 Cialdini, R. B., Borden, R. J. and Thorne, A. (1976) 'Basking in reflected glory: Three (football) studies', Journal of Personality and Social Psychology, Vol. 34, No. 3, pp. 366-375.

33 Bristow and Sebastian (2001) op. cit.

34 Aronson, E. and Mills, J. (1959) 'The effect of severity of initiation on liking for a group', Journal of Abnormal and Social Psychology, Vol. 66, pp. 177-181.

35 Gerard, H. B. and Mathewson, G. C. (1966)

'The effects of severity of initiation on liking for a group: a replication', Journal of Experimental Social Psychology, Vol. 2, pp. 278-287.

36 Bristow and Sebastian (2001) op. cit. 